\title{
INTUMESCENCES ON POPLAR LEAVES. I. STRUCTURE AND DEVELOPMENT ${ }^{1}$
}

\author{
Cart D. La Rue \\ (Received for publication April 12, 1932)
}

\section{INTRODUCTION}

The peculiar wart-like outgrowths of cells on leaves and stems, which were named "intumescences" by Sorauer (12), have been observed on a number of plants. Sorauer himself found them on more than a dozen plants, and other workers have recorded their occurrence on plants of various families. They have been found on both monocotyledonous and dicotyledonous angiosperms, on gymnosperms, and even on ferns. Viala and Pacottet (14) found them on the cultivated grape; Dale (2) on Hibiscus vitifolius; Steiner (13) on Ruellia formosa, and Aphelandra porteana; Atkinson (I) on the apple, and the tomato; Douglas (3) on the potato; and Von Schrenk (15) on the cauliflower. Cabbage plants have been observed to develop intumescences under differing conditions by Harvey (5), and Wolf (I7). Schilling (II) coated twigs of a number of plants with paraffin, or vaseline, with the result that intumescences were formed. Hahn, Hartley, and Rhoades (4) observed such growths on roots of several species of conifers. Küster $(6,7)$ studied the intumescences on leaves of Populus tremula, and on the pods of Pisum sativum, Vicia faba, and other leguminous plants; and Wallace (16) investigated the intumescences produced by the action of ethylene gas on apple twigs. Numerous other examples of these abnormalities are cited in the literature, which is reviewed by Küster (8).

In connection with a study of regeneration the author (9) discovered intumescences on leaves of Populus tremuloides, and P. grandidentata, in which he was trying to induce renewed growth. He has found these growths also on leaves of Eucalyptus cornuta, of E. coccifera, and of Thurberia sp. grown in the greenhouse, and on injured leaves of Mitchella repens (IO) and of Hieracium venosum.

In connection with the work on regeneration mentioned above, leaves of a number of species of plants were cut into pieces and placed on plates of nutrient agar, or floated on nutrient solutions, to test their capacities for regeneration. Most of these trials were without result so far as any outgrowth was concerned, but it was noticed that the leaves of Populus grandidentata soon

1 Paper No. 373 from the Dept. of Botany, University of Michigan. A part of this work was done at the University of Michigan Biological Station. 
produced growths on the surfaces next to the agar, or the nutrient solution. These were thought, at first, to be evidences of regeneration, but it soon became apparent that they were incapable of continued growth, and were intumescences. Shortly aiter these growths were found on leaves of $P$. grandidentata, similar ones were discovered on leaves of $P$. tremuloides. Repeated trials showed that the growths could be developed at will, not only on agar plates and on nutrient solutions, but also when the leaf pieces were floated on water in a closed chamber. Next, it was found that whole leaves of these two species of poplar would throw out intumescences without being in contact with an agar surface or a water surface, if they were only enclosed in an air-tight chamber. It did not seem to make any difference whether the leaves were removed from the twigs, were left on the twigs, or were left attached to the trees. However, some differences in the rate of development were found under differing conditions, and the causes of these outgrowths were investigated in some detail. The details of these studies and their results will be presented in a later paper.

\section{INTUMESCENCES ON POPLAR LEAVES IN NATURE}

After the discovery of the artificially induced intumescences on poplar leaves a search was made for such abnormalities in nature. They were never found on leaves fully exposed to the air, a result that might have been predicted from other studies on such growths on other species. An abundance of moisture has been found necessary to the formation of such abnormalities in most species, and in the open air such a supply of moisture is rarely encountered. However, various species of insects roll the leaves of plants to form chambers for the development of their larvae, and such chambers were found on both of the poplar species concerned. Wherever the leaves were rolled tightly narrow chambers were formed to which the access of the dry outer air was somewhat restricted, and in these chambers intumescences were found. Sometimes only a very small number of intumescences would be found on the leaf, and considerable areas of leaf would occur from which the mesophyll had been eaten by the insect larvae. It is obvious that the breaking of the epidermis by the long, abnormal cells of the outgrowth gives an easy access to the soft mesophyll cells, which the larvae can attack at once without the necessity of gnawing through the relatively tougher epidermis. It is not too much to suppose that these insects have come to depend, to a limited degree, on this reaction of the leaf to the unusual condition presented by the rolling of the lamina; although, since the larvae can and do eat the epidermis, it is possible that the advantages offered in the form of intumescences are of no consequence to them.

Certain insects make webs by which they fasten leaves of Populus grandidentata together in pairs. Wherever these leaves were pressed close together in forming a larval chamber conditions favorable to intumescences 
were supplied, and usually intumescences were found in such chambers. Here, too, the larvae consumed the cells of the intumescences, and if the larvae were near maturity when found, only a few small outgrowths around the outside of the areas attacked by the larvae would be seen.

Leaves of $P$. tremuloides were fastened together in the same way as those of $P$. grandidentata, but whether by the same species of insect or not, has not been determined. So far as the outgrowths were concerned the conditions in the two species of poplar were identical.

Aside from the examples of insect attack, no intumescences have ever been found on normal poplar leaves. It is unusual for the conditions which are needed for the inception of such outgrowths to be supplied by the normal environment of the plant, which may be considered fortunate for the health of the species concerned; otherwise the abnormal lesions of the epidermis would give entry to destructive organisms with great damage to the leaves as a possible result.

\section{SPECIES STUDIED}

No species of Populus other than the two already mentioned has been found on which intumescences will develop, under any of the conditions which have been tried. Repeated attempts to induce them on $P$. deltoides, $P$. balsamifera, $P$. alba, $P$. simonii, and $P$. nigra var. italica were without result.

It seems curious that two species of Populus should behave so differently from the others, but the conditions which give rise to intumescences in these species do not have the same effect on most other kinds of plants. In the attempt to see whether plants of other families and genera would react in like manner the following species were enclosed in damp chambers; in all cases except one, quite without result:

Polypodiacae

Pteris aquilina

Polystichum lonchitis

Aspidium thelypteris

Cystopteris bulbifera

Osmundaceae

Osmunda regalis

Ophioglossaceae

Botrychium simplex

Botrychium virginianum

Equisetaceae

Equisetum arvense

Equisetum sylvaticum

Equisetum laevigatum

Equisetum hycmale

Equisetum scirpoides

Lycopodiaceae

Lycopodium lucidulum

Lycopodium clavatum
Lycopodium obscurum var. dendroideum Isoetaceae

Isoetcs sp.

Taxaceae

Taxus canadensis

Pinaceae

Sequoia sempervirens

Pinus resinosa

Larix laricina

Picea mariana

Abies balsamea

Tsuga canadensis

Thuya occidentalis

Junipcrus communis

Juniperus horizontalis

Juniperus virginiana

Cupressus lawsoniana

Typhaceae

Typha latifolia 
Gramineae

Phleum pratense

Agropyron repens

Cyperaceae

Eleocharis rostellata

Araceae

Symplocarpus foetidus

Acorus calamus

Commelinaceae

Tradescantia virginiana

Commelina bangalensis

Liliaceae

Aloe ciliaris

Erythronium americanum

Clintonia borealis

Smilacina racemosa

Maianthemum canadense

Polygonatum biflorum

Smilax herbacea

Iridaceae

Iris versicolor

Iris lacustris

Orchidaceae

Epipactis repens var. ophioides

Salicaceae

Salix lucida

Salix longifolia

Myricaceae

Myrica gale

Myrica asplenifolia

Juglandaceae

Juglans nigra

Betulaceae

Corylus americana

Corylus rostrata

Betula alba var. papyrifera

Alnus incana

Fagaceae

Fagus grandifolia

Quercus borealis

Quercus velutina

Urticaceae

Ficus rubescens

Ulmus americana

Humulus lupulus

Morus alba

Santalaceae

Comandra umbellata

Polygonaceae

Rumex acetosella

Polygonum amphibium

Fagopyrum esculentum

Chenopodiaceae

Chenopodium album
Caryophyllaceae

Lychnis alba

Saponaria officinalis

Nymphaeaceae

Nelumbo lutea

Magnoliaceae

Magnolia sp.

Cruciferae

Matthiola incana

Lepidium virginicum

Brassica nigra

Radicula aquatica

Sarraceniaceae

Sarracenia purpurea

Droseraceae

Drosera rotundifolia

Drosera longifolia

Crassulaceae

Sedum acre

Sedum spurium

Sedum allantoides

Sedum stahlii

Crassula arborescens

Cotyledon fulgens

Echeveria pulvinata

Echeveria clavaria

Bryophyllum calycinum

Bryophyllum crenatum

Saxif ragaceae

Saxifraga sarmentosa

Ribes floridum

Hamamelidaceae

Hamamelis virginiana

Rosaceae

Pyrus malus

Amelanchier spicata

Crataegus sp.

Fragaria virginiana

Geum rivale

Rubus alleghenicnsis

Rosa sp.

Prunus serotina

Prunus virginiana

Prunus pennsylvanica

Prunus pumila

Leguminosae

Acacia riceana

Gleditsia triacanthos

Robinia pscudo-acacia

I inaceae

Reinwardtia indica

Simarubaceae

Ailanthus glandulosa 
Euphorbiaceae

Ricinus communis

Anacardiaceae

Rhus typhina

Celastraceae

Evonymus variegatus

Evonymus aurcus

Aceraceae

Acer saccharum

Acer rubrum

Melianthaceae

Melianthus major

Balsaminaceae

Impatiens biflora

Impatiens sultani

Tiliaceae

Tilia americana

Malvaceae

Althea rosea

Malva rotundifolia

Hibiscus tiliaceus

Hibiscus rosa-sincnsis

Begoniaceae

Begonia sharffiana

Begonia peltata

Begonia phyllomaniaca

Eleagnaceae

Shepherdia canadensis

Lythraceae

Decodon verticillatus

Myrtaceae

Myrtus communis

Onagraceae

Oenothera biennis

Fuchsia hybrida

Araliaceae

Hedera helix

Cornaceae

Cornus canadensis

Cornus circinata

Cornus florida

Ericaceae

Aucuba japonica

Pyrola elliptica

Ledum groenlandicum

Kalmia polifolia

Andromeda glaucophylla

Chamaedaphne calyculata

Gaultheria procumbens

Arctostaphylos uva-ursi

Gaylussacia baccata

Vaccinium pennsylzanicum

Vaccinium macrocarpon
Oleaceae

Fraxinus americana

Ligustrum japonicum

Ligustrum vulgare

Gentianaceae

Menyanthes trifoliata

Apocynaceae

Vinca major

Nerium oleander

Apocynum cannabinum

Asclepiadaceae

Asclepias incarnata

Asclepias syriaca

Hoya carnosa

Boraginaceae

Cynoglossum officinale

Labiateae

Coleus blumei

Nepeta hederacea

Stachys lanata

Solanaceae

Solanum lycopersicum

Solanum tuberosum

Solanum dulcamara

Solanum miniatum

Nicotiana glauca

Lycium halimifolium

Scrophulariaceae

Antirrhinum majus

Veronica americana

Veronica speciosa

Verbascum thapsus

Lentibulariaceae

Utricularia vulgaris var. americana

Plantaginaceae

Rubiaceae

Plantago major

Mitchella repens

Caprifoliaceae

Diervilla lonicera

Viburnum acerifolium

Viburnum cassinoides

Sambucus canadensis

Sambucus racemosa

Compositae

Solidago sp.

Aster laevis

Helichrysum petiolatum

Antennaria sp.

Erigeron canadensis

Lactuca canadensis

Taraxacum officinale

Hieracium venosum

Kleinia articulata 
The one exception mentioned was Thuy'a occidentalis, which in one case developed a single intumescence, but could not be induced to produce any more. Mitchella repens, with which the writer has carried on numerous experiments (IO), often develops intumescences of the mesophyll when the epidermis has been removed, but unless this is done none ever appear. Many of the plants listed have been tried a number of times and it appears that the formation of intumescences on leaves enclosed in damp chambers is decidedly unusual. It is strange that tomato plants, which have been reported by Atkinson ( $I$ ) to produce intumescences in atmospheres of excessive humidity, and potatoes, which according to Douglas (3) develop these growths under similar conditions, have not as yet given such results in this study. It is possible that the variety used is of importance, but neither of these writers mentioned the varieties which they studied, so one is left in doubt concerning these species.

The behavior of Populus tremuloides is so nearly like that of $P$. grandidentata that it is unnecessary to give a detailed account of each species. In instances where $P$. tremuloides differs notably from the more carefully studied $P$. grandidentata, the fact will be noted; otherwise agreement between the two species may be assumed.

\section{AGE OF LEAVES}

The age of the leaves which will produce intumescences seems not to be a matter of much importance. It has been found that very young leaves, just emerging from the bud, will not react in this way; but as soon as they reach about half their full size they become susceptible. At first it was thought that the heavy coating of hairs which cover the young leaves might have an effect in the process. However, these hairs remain on the leaves until they are nearly or quite mature, though of course they are more widely spaced as the leaves enlarge. Removal of the hairs from very young leaves does not bring about any change in their reaction, and their removal from half-grown leaves does not increase the number or the size of the outgrowths. It is most likely that these young leaves have been subjected in the bud to just those conditions which induce intumescences on the older leaves, and they are conditioned to such circumstances to such an extent that they do not suffer from a return to such an environment. The older leaves may have been removed from such surroundings long enough to have lost their tolerance of them, so that they react when returned to them. So little is known about such matters that anything one may say about them is mere conjecture.

Very old leaves at the end of the summer have failed to react in the trials which have been made in three successive seasons, although in several tests leaves which had developed some autumn coloring still were capable of developing intumescences of the usual type. Leaves which appear very dry, even in mid-summer, will not react in the typical way, perhaps because they are sub-normal in their physiological activities. It is possible that they are 
low in carbohydrate content, though this has not been proved. Dusty leaves, found where dust from roads has settled over them, usually fail to give rise to any outgrowths.

In general leaves from all parts of the tree react in the same way, and give well-deyeloped intumescences without regard to their position on the tree. However, the leaves produced by young root-sprouts rarely develop many intumescences, though those from young trees of a somewhat larger size give normal results.

\section{LOCATION OF THE ABNORMAL OUTGROWTHS}

The outgrowths may be found on all parts of the leaf. They are usually abundant and well-developed on the petioles whether these have laminae attached to them or not. On the laminae the growths are scattered in what appears at first to be a random fashion, but more careful observation reveals the fact that they are always in close connection with the veins or veinlets of the leaf; in fact it seems that it is very unusual for them to originate in a vein islet. The most abundant outgrowths as well as the largest ones are found alongside, or directly on the midrib and the larger veins. This is quite different from the findings of Viala and Pacottet (14), who report that they never found any intumescences on the veins of leaves of the grape.

The lower epidermis of the leaf blade usually shows the greatest number of the abnormalities, although some leaves have more on the upper epidermis than on the lower. Leaves may be seen in which there seems to be about an equal number on both surfaces, and on such leaves the number is commonly very great. It is nuch more usual to find a considerable number of outgrowths on the lower surface, and none on the upper, than to encounter the reverse condition.

\section{PARTS OF LEAVES INVOLVED}

Intumescences on the upper surface may involve only the upper layer of the palisade or both layers of palisade. In normal leaves of both Populus grandidentata and Populus tremuloides only two layers of palisade are present, as is shown in table 2. In no case was a larger number of layers found in these species, either in the normal leaves, or in those bearing intumescences. Neither has any case been found where an outgrowth on the upper surface involved the spongy parenchyma.

Normal leaves of Populus grandidentata show three, four, or rarely five layers of spongy parenchyma (table I). The number of layers of spongy parenchyma in Populus tremuloides is slightly larger. Five cell layers is the most common number, but four, six, and seven layers are found. Intumescences on the lower surface may involve only the layer of cells next to the lower epidermis; they may extend to the first two layers; or they may influence all the cells of the sponge which are included in the area affected by the disturbance without affecting at all the layers of palisade. In all cases, how- 
ever, the cells nearest the epidermis show the greatest enlargement. This is equally true of the cells included in the swellings on the upper surfaces of leaves.

TABLE I. Numbers of Layers of Cells in Normal Poplar Leaves and in Leaves with Intumescences

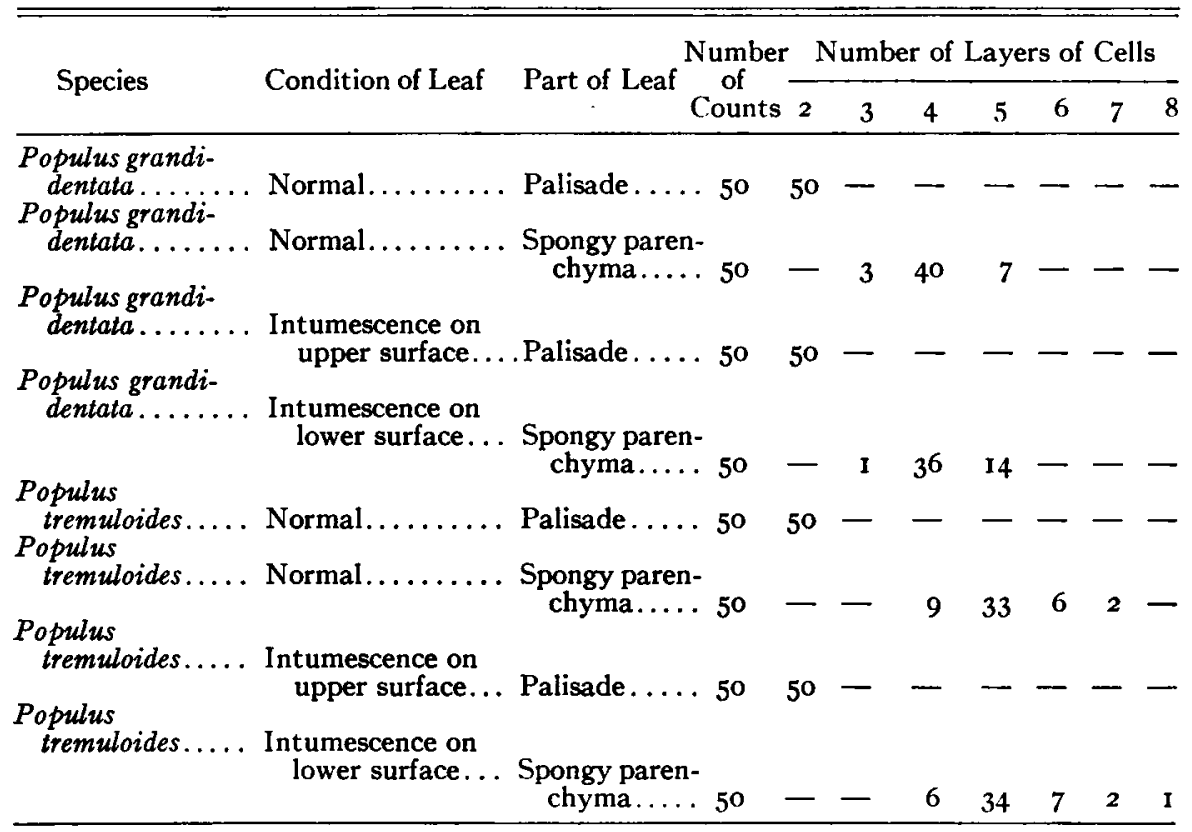

In intumescences on veins, which are usually very well developed, the outermost layer of cells is most affected, but changes may be seen in all cells outside the bundle sheaths.

The cells of the epidermis do not take part in the formation of these outgrowths. If an intumescence is small, the epidermis may be stretched by the extension of the cells inside it, but not ruptured. In the growth of large intumescences the epidermis can not be stretched enough to allow for the great increase in cell size, and it is finally torn and turned back by the protruding cells. In no case was it found that the cells of the epidermis were enlarged in the process, so the intumescences prove to be growths of the mesophyll alone.

Outgrowths on the petioles usually involve all the cells in the affected area between the epidermis and the sheaths of the vascular bundles. As is the case with the laminae of the leaves, some intumescences may appear which affect only the outermost layer of the tissue inside the epidermis, while larger ones may bring about the swelling of all the cells outside the vascular bundles. The outermost layers are always more noticeably changed than those which 
lie deeper in the petiole. The epidermis is ruptured by the large intumescences, but its cells are not enlarged.

\section{THE INTUMESCENCES AS HYPERTROPHIES}

Intumescences may be hypertrophies, in which the original cells of the tissue are enlarged, but not increased in number as a result of the disturbance; or they may be hyperplasias, in which the number of cells is increased while the size of the individual cells remains the same as those of the normal tissue. Some examples appear to be mixtures of the two types of growth. The growths which were observed in this study are hypertrophies. This is proved by the failure to find any division figures, or any other evidence of renewed cell division in the leaf. Table I shows that the number of cell layers in the leaves is not changed by the development of the intumescences. That the size of the abnormal cells is much greater than that of normal cells is shown very clearly by table 2 . The greatest cell length from an intumescence on

TABLE 2. Lengths of Normal Cells and of Cells of Intumescences in Populus grandidentata. Measurements are Given in $\mu$

\begin{tabular}{|c|c|c|c|}
\hline Type of Cell & $\begin{array}{l}\text { Number } \\
\text { of } \\
\text { Variates }\end{array}$ & $\begin{array}{c}\text { Range of } \\
\text { Measure- } \\
\text { ments }\end{array}$ & Average \\
\hline $\begin{array}{l}\text { Normal cells, lowest layer of spongy mesophyll. } \\
\text { Normal cells, second lowest layer of spong }\end{array}$ & gy 150 & $6.9-17.2$ & 10.7 \\
\hline & I $8 \mathrm{I}$ & $6.9-24.1$ & 14.5 \\
\hline $\begin{array}{l}\text { Normal cells, upper layer of palisade } \\
\text { Cells of intumescences on lower surfa }\end{array}$ & 158 & $24.1-51.6$ & $\begin{array}{l}40.1 \\
62.8\end{array}$ \\
\hline $\begin{array}{l}\text { Cells of intumescences on lower surface of leaf.. } \\
\text { Cells of intumescences on upper surface of leaf.. }\end{array}$ & $\begin{array}{ll}\ldots \text { ror } \\
. .\end{array}$ & $\begin{array}{l}37.8-99.8 \\
4 \mathrm{I} \cdot 3-68.8\end{array}$ & $\begin{array}{l}62.8 \\
57.2\end{array}$ \\
\hline
\end{tabular}

the lower surface of a leaf is more than fourteen times that of the least length of normal cells of the spongy parenchyma. The longest hypertrophied cell of the upper layer of the palisade is more than seven times as long as the greatest measurement recorded in the table for normal cells from the same region. Since no attempt was made to choose the very largest intumescences for measurement of the cells, it is likely that even larger cells may be encountered in such growths.

The cells of the intumescences are not often much elongated in the plane parallel to the surface of the leaf. It is not likely that there is any polarity about the process; but probable that the cells expand most where there is most space available. In the leaves of Populus grandidentata, and $P$. tremuloides the spongy mesophyll is rather close in texture and does not allow much room for the expansion of any one cell. If each of the cells of the intumescence swells a little, all the space is packed tight, and further expansion must be outward. In the palisade layers, especially the upper layer, where the cells normally stand very close together, there is even less room for lateral expansion, and the cells of intumescences elongate and push out, with little or no lateral expansion. 


\section{CHANGES IN THE HYPERTROPHIED CELLS}

Aside from the fact that the cells increase in size to an amazing degree, they do not undergo any striking change. They do not become separated from one another except at the outer ends where they grow out to a different extent. Here it appears that the separation is due to differential growth of
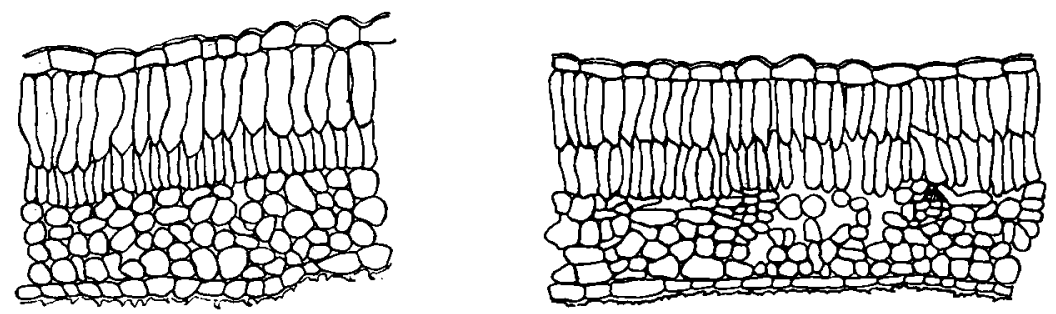

Text Figs. I and 2. Fig. I (left). Section of a normal leaf of Populus grandidentata. FIG. 2 (right). Section of a normal leaf of Populus tremuloides.

the outer ends of the cells, and not to any splitting apart of the walls. In the other parts of the intumescences the cells seem to elongate simultaneously, so that there is a general growth which prevents the cells from being torn apart. Even the outer cells remain firmly attached to the others, in direct contrast to the cells in many similar types of abnormal growth.

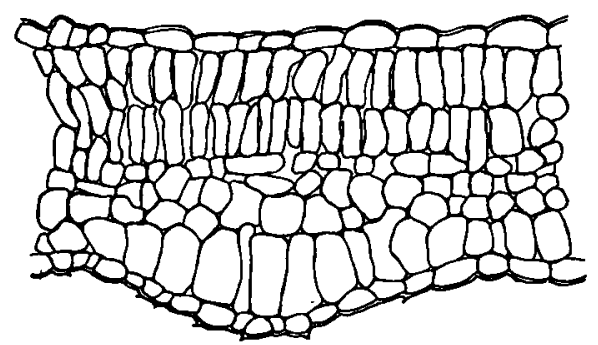

Text Fig. 3. Intumescence developing on lower surface of a leaf of Populus grandidentata, which has been kept 72 hours in a damp chamber.

The increase in cell size takes place by the growth of the walls, and there is no evidence that the walls are thinned by stretching. Neither does any sign of the corrosion or digestion of any of the layers of the cell walls appear, although detailed measurements of the thickness of walls of normal and hypertrophied cells have not been made. Careful study of the walls has failed to reveal any thinned areas, such as have been reported for intumescences in some other plants.

The enlarged cells have one or two very large vacuoles, and often the protoplasm between the two vacuoles of a cell gives an appearance of cell division, the true nature of which is discovered by more careful examination. 
The layers of protoplasm along the cell walls appear to be thinned out somewhat by the great increase in cell surface, but do not appear abnormal in any

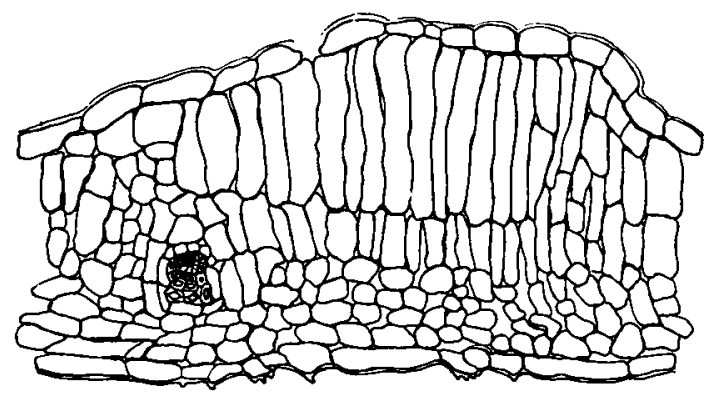

TEXT Fig. 4. Intumescence developing on the upper surface of a leaf of Populus grandidentata, which has been kept 96 hours in a damp chamber.

other respect. The chloroplasts do not increase in number in hypertrophied cells, and accordingly they are separated more widely than in normal cells. Examination of the living cells shows them to be still green, although their wide separation makes the tissue appear nearly colorless to the naked eye. Neither in living material nor in stained sections do they appear distorted or

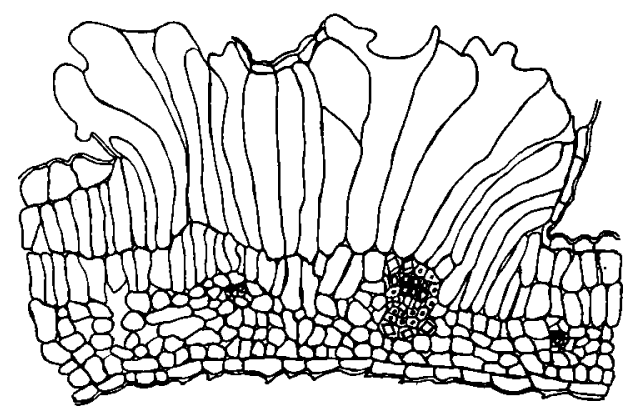

TExT FIc. 5. Intumescence on upper surface of a leaf of Populus grandidentata after 6 days in a damp chamber.

abnormal in any way. No crystals have been observed in these cells, though they are common along the vascular bundles in the cells of the bundle sheaths, in both normal leaves and those which have been enclosed in damp chambers. It does not appear that these crystals are more numerous in the experimental than in the normal leaves.

\section{RATE OF DEVELOPMENT}

Sections were made of leaves taken from the experimental chambers at twenty-four-hour intervals to determine the rate of change in the cells affected by the abnormal environment. At the end of forty-eight hours no changes of any kind could be detected (text figs. I, 2), but after seventy-two 
hours some cells showed considerable swelling (text fig. 3 ), which sometimes was more pronounced in a transverse direction than in the longitudinal one. This swelling fills up a considerable part of the air space in the spongy paren-

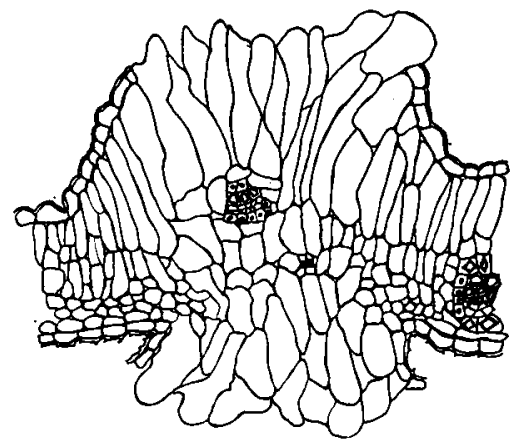

Text Fic. 6. Intumescences on both surfaces of a leaf of Populus grandidentata, which has been in a damp chamber for 6 days.

chyma, and may not cause any distension of the epidermis although in many cases the cells are more than doubled in size, and the epidermis is forced outward for a considerable distance.

After 96 hours the cells have taken up all the free space within the leaf, and have begun to thrust the epidermis outward, but the tension is usually not yet great enough to rupture it (text fig. 4). At the end of I20 hours the

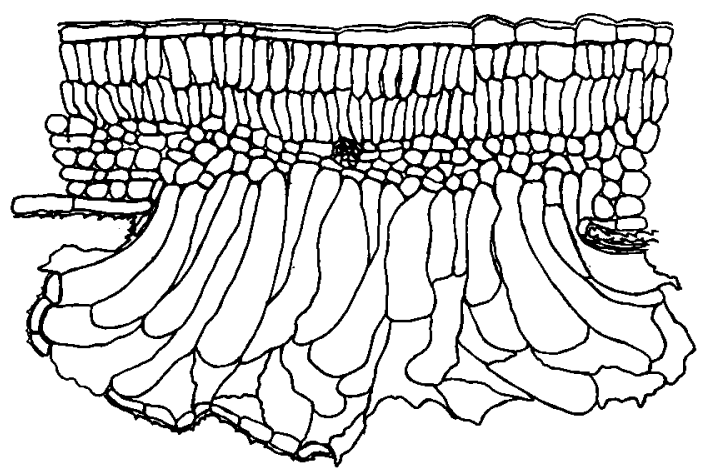

Text Fig. 7. Intumescence on lower surface of leaf of Populus grandidentata, which has been kept 9 days in a damp chamber.

epidermis shows numerous breaks through which the cells are beginning to protrude, and at this time the intumescences can be detected easily by the naked eye.

When the leaves have been in the damp chamber for I 44 hours the intumescences are for the most part fully developed, although some may have been delayed in beginning their growth and are still immature (text figs. 5, 6). The epidermis has now been turned back by the swelling of the tissue inside. 
and may show collapse of some of its cells. From this time on little change takes place in the intumescence (text figs. $7,8,9$ ), although there are always some which grow to an unusual size, and these will not have reached their

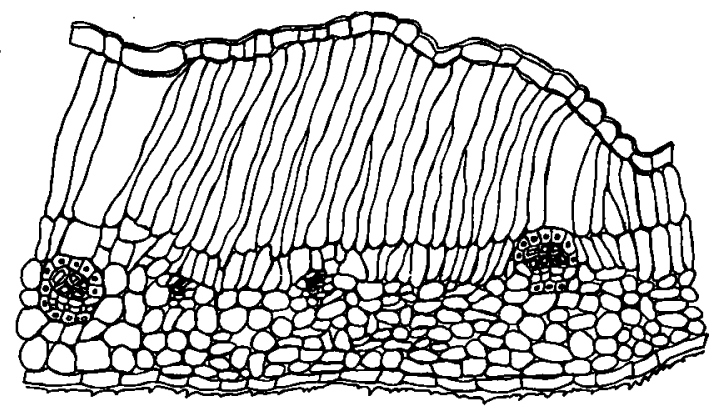

Text Fig. 8. Intumescence on upper surface of a leaf of Populus tremuloides, which has been kept 9 days in a damp chamber.

full extension as yet. Most of the cells appear to remain unchanged for several days after this, but by that time the leaves begin to show a general decline, or they are cut off from the twig by abscission. In parts of leaves which have been sterilized and placed on nutrient agar, the life of the cells is considerably prolonged, and the greatest extension of intumescences has been observed on such specimens. But under the ordinary conditions in the damp chambers, the outgrowths begin to collapse and decay as soon as the leaves begin to look unhealthy, a state which they usually reach after eight or ten days.

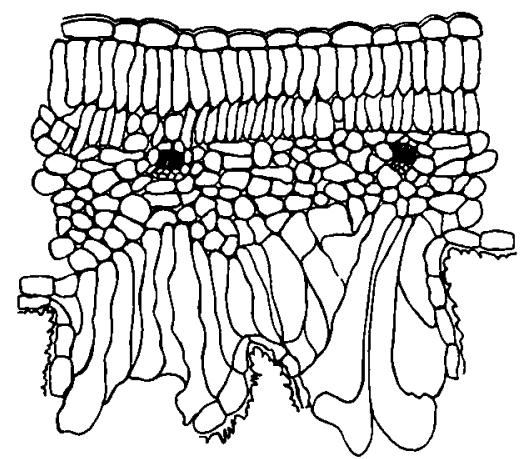

Text Fig. 9. Intumescence on lower surface of a leaf of Populus trcmuloides, which has been kept 12 days in a damp chamber.

\section{FATE OF THE INTUMESCENCES}

The outgrowths are never cut off by a periderm layer in poplar leaves. The conditions under which they develop are not conducive to the development of periderm; although Dale (2) found that the intumescences on Hibiscus vitifolius were sometimes cut off by a layer of periderm, presumably while subjected to a similar environment. Whether such a result would be reached 
in the open air can not be ascertained, because after the leaves have been kept in a damp chamber for a time long enough to allow intumescences to develop they are no longer able to endure the dry open air, and they speedily wilt and die. For the same reason one can not tell whether the intumescences would dry down in the open air, although that would almost certainly occur if the leaves could be kept alive long enough. Why the leaves should lose their ability to endure the drought of the open air, after a few days in a damp chamber, is not yet known, but the experience of the writer suggests that such a change takes place in leaves of most specimens of plants which have been subjected to such conditions.

\section{DISCUSSION}

There seems to be no law as to the development of intumescences within groups of plants. Certain species in a genus may react in this way while related species seem immune. Thus Küster (6) could produce outgrowths on Populus tremula at will, but was unable to secure them on $P$. pyramidalis and $P$. candicans; and the writer was able to cause their production on $P$. grandidentata and $P$. tremuloides and not at all on $P$. deltoides, $P$. balsamifera, $P$. alba, $P$. simonii, or $P$. nigra var. italica. Furthermore these growths have been found in widely separated families, while intermediate families have not been shown to produce them. Naturally, it is not likely that all possible cases have been noted, but so far as one set of environmental conditions is concerned in their formation, they have been sought in a large number of plants. It is not always possible to secure the same results as other investigators have recorded, as was seen by Küster when he failed to cause the growth of intumescences on Vitis and Epilobium, which had been reported previously. The writer failed to secure the results with tomato and potato, reported by Atkinson ( $\mathrm{I}$ ) and by Douglas (3).

The leaf is most often the organ on which intumescences arise, but Sorauer (I2), Schilling (II), and Wallace (16), have found them on twigs; Dale (2) reported them on flowers and fruits; and Hahn, Hartley, and Rhoades (4) observed them on roots.

The part of an organ on which they develop shows a certain amount of variation in different plants. On leaves the lamina is most often involved, but Küster (6), as well as the writer, found them on petioles. Where they appear on the leaf lamina, they are usually seen on both upper and lower surfaces, as has been observed by Sorauer, Küster, and Wolf (I7). In this investigation they have been found on both surfaces of leaves of both species concerned (text fig. 6). Viala and Pacottet (I4), however, say that they were able to find such abnormalities on the lower surface only. They report that no intumescences were found on the veins of the grape leaf, which is quite contrary to the findings of Sorauer, Küster, and the writer, who found them most abundant and best developed along the midribs and the large veins.

Intumescences are not always alike in structure, for they may consist en- 
tirely of swollen cells, or they may be made up of cells not noticeably increased in size but greatly augmented in number. Again, they may represent a mixture of the two preceding types of tissue modification. To the first group, or hypertrophies, the intumescences on cabbage reported by Wolf belong, as well as those studied by Küster on Populus tremula, and by Viala and Pacottet on the grape. Those concerned in the present investigation on Populus grandidentata and $P$. tremuloides are certainly hypertrophies, and no increase in the number of cells has ever been found in them. Sorauer has figured hypertrophies on Cassia tomentosa and Ficus elastica.

Hyperplasias, which consist of masses of cells greatly increased in number, are common in intumescences. Steiner (I3) published figures of such growths on Ruellia formosa and Aphelandra porteana; and Hahn, Hartley, and Rhoades have shown that the outgrowths which they studied on roots of conifers are of this nature.

In several plants, intumescences have been found which consist of enlarged cells which have been increased in number as well. Sorauer, Von Schrenk, Douglas, Wallace, and Dale have described abnormalities of this nature. Apparently the type of growth is determined by the nature of the stinulus which causes it, rather than by the species concerned; for Wolf found hypertrophies on cabbage leaves caused by wind-blown sand, while Harvey (5) found that freezing produced hyperplasias on leaves of the same plant.

The hypertrophies on Populus grandidentata and $P$. tremuloides consist of cells which have become greatly enlarged so that they push out from the leaf and rupture the epidermis. There is no evidence of a solution of cell walls such as Wallace ( I6) has clescribed, nor do the cells ever become freed from each other or from the cells in the interior of the leaf. It is obvious that the growths on poplar leaves are very different from those on apple twigs described by Wallace. Externally the two types of growth are not much alike, and can be classed together only on the ground that both are small eruptions. However, it is probably not well at present to give new names to the two types into which one can readily divide the intumescences thus far described. The swelling of the cells described by Wallace has been found in a more exaggerated form on poplar leaves. Another feature common to the intumescences on apple twigs and those on poplar leaves is the development of two large vacuoles in many of the cells which gives an appearance of cell division.

Little is said about the rate of development of intumescences in the studies which have been made. Küster tells of their development on shells of peas within 24 hours, which is probably the most rapid growth recorded for any of these eruptions. Wallace found that in the apple responses might take place within 48 hours, or might be delayed for as long as six days. On leaves of Populus grandidentata and P. tremuloides a minimum time of 72 hours is needed for the outgrowths to become apparent, but many of them may not be initiated until a day or two later. 
The difficulties which prevent the discovery of the fate of intumescences on poplar leaves, and which are inseparably correlated with the conditions of their development, have been discussed. Wallace and Dale have found that the growth of a layer of periderm may cut off the intumescences for normal tissues of the plants which they studied, but no evidence of periderm formation has been found in poplar leaves.

A discussion of the stimuli which initiate intumescences in the various plants on which they occur is reserved for a later paper.

\section{SUM MARY}

I. This paper reports the results of a study of the structure and development of intumescences on leaves of Populus grandidentata and P. tremuloides.

2. The intumescences develop rapidly on leaves confined in damp chambers, but are found in nature only on leaves which have been rolled or fastened together in pairs by insects.

3. Populus grandidentata and P. tremuloides are the only species of the genus which this study has shown to be capable of producing intumescences. Populus deltoides, $P$. balsamifera, $P$. alba, $P$. simonii, and $P$. nigra var. italica never produced intumescences under any of the conditions to which they were subjected.

4. Leaves of all ages, except those just ready to fall and those which have just emerged from the bud, are capable of developing intumescences.

5. The outgrowths occur on both laminae and petioles. On the laminae they appear on both upper and lower surfaces, but are most abundant on the lower surface. On either surface they are most abundant along the midribs and the larger veins.

6. The outgrowths are due to swelling of the cells, which are not increased in number. Therefore the abnormalities are to be considered hypertrophies.

7. The hypertrophied cells do not separate from one another, and no dissolution of any layers of the cell walls has been observed.

8. The leaves must be kept in damp chambers for three days before the outgrowths become apparent.

9. Under the conditions of these experiments, no periderm develops between the intumescences and the normal tissue of the leaves.

DeparTMENT OF Botany,

UNIVERSITY OF MICHIGAN,

ANN ARBoR, Michigan

\section{LITERATURE CITED}

I. Atkinson, G. F. 1893. Oedema of the tomato. Bull. Cornell Agr. Exp. Sta. 53: I-108.

2. Dale, Elizabeth. I90I. Investigations on the abnormal outgrowths or intumescences, on Hibiscus vitifolius Linn. Phil. Trans. Roy. Soc. London B, 194: $163-182$. 
3. Douglas, Gertrude E. 1907. The formation of intumescences on potato plants. Bot. Gaz. 43: 233-250.

4. Hahn, G. G., C. Hartley, and A. Rhoades. 1920. Hypertrophied lenticels on the roots of conifers and their relation to moisture and aeration. Jour. Agr. Res. 20: $253-266$.

5. Harvey, R. B. 1918. Hardening process in plants and developments from frost injury. Jour. Agr. Res. 15: 83-II2.

6. Küster, E. 1903. Über experimentelle erzeugte Intumescenzen. Ber. Deutsch. Bot. Ges. 21 : $452-458$.

7. - I906. Histologische und experimentelle Untersuchungen über Intumescenzen. Flora 96: 527-537.

8. - I9I6. Pathologische Pflanzenanatomie. Jena.

9. La Rue, C. D. 1930. Regeneration in some American mosses. Papers Michigan Acad. Sci. Arts and Letters II: 225-24I.

10. - 1931. The water supply of the epidermis of leaves. Papers Michigan Acad. Sci. Arts and Letters 13: 13I-139.

II. Schilling, E. 1915. Über hypertropische und hyperplastische Gewebeswucherungen an Sprossachsen, versacht durch Paraffine. Jahrb. Wiss. Bot. 55: 177-258.

12. Sorauer, P. 1899. Über Intumeszenzen. Ber. Deutsch. Bot. Ges. I7: 456-460.

I3. Steiner, R. 1905. Über Intumeszenzen bei Ruellia formosa und Aphelandra Porteana. Ber. Deutsch. Bot. Ges. 23: I05-II3.

14. Viala, P., and P. Pacottet. 1904. Sur les verrues des feuilles de la vigne. Compt. Rend Acad. Sci. Paris 138: 161-163.

15. Von Schrenk, H. I905. Intumescences formed as a result of chemical stimulation. Rept. Missouri Bot. Gard. I6: 125-148.

16. Wallace, R. H. 1928. Histogenesis of intumescences in the apple induced by ethylene gas. Amer. Jour. Bot. I5: 509-524.

17. Wolf, F. A. I918. Intumescences, with a note on mechanical injury as a cause of their formation. Jour. Agr. Res. 13: 253-259. 